\title{
KONSEP PROFESI KEGURUAN MI
}

\author{
Oleh: \\ Khanif Maksum \\ (Dosen PGMI Sekolah Tinggi Ilmu Agama Alma Ata Yogyakarta)
}

The Professional work which requires some sciences, it be learned and then applied to the public interest. Based on the requiring above, this professional job is different from other jobs where a profession requiring the specialized skills and expertise in carrying out his/her profession. Teacher is a professional work, and as a professional work, it must meet certain qualifications. Therefore, it needs many requirements, ig a good motivation, knowledge and skills, dedication, ethics, and entitled to a reward. The professional work involves intellectual activity, distinct body knowledge, and requires long preparation to do, continue service training, a career and a life of permanent membership, behavior, concerned deal with service, having professional organizations, and adherent code of conduct by members.

Keywords: Professionalism

\section{A. PENDAHULUAN}

Profesionalisme merupakan sikap professional yang berarti melakukan sesuatu sebagai pekerjaan pokok sebagai profesi dan bukan sebagai pengisi waktu luang atau sebagi hobi belaka. Seorang professional mempunyai kebermaknaan ahli dengan pengetahuan yang dimiliki dalam melayani pekerjaannya. Tanggung jawab atas keputusannya baik intelektual maupun sikap, dan memiliki rasa kesejawatan menjunjung tinggi etika profesi dalam suatu orgaisasi yang dinamis. Seorang professional memberikan layanan pekerjaan secara terstruktur. Hal ini dapat dilihat dari tugas personal yang mencerminkan suatu pribadi yaitu terdiri dari konsep diri dan realita atau kenyataan dari sendiri.

Profesi merupakan pekerjaan yang di dalamnya memerlukan sejumlah persyaratan yang mendukung pekerjaannya. karena itu, tidak semua pekerjaan menunjuk pada sesuatu profesi. untuk memahami lebih dalam, menurut robert $\mathrm{w}$. richey sebagaimana dikutip oleh suharsimi arikunto, memberi batasan ciri-ciri yang terdapat pada profesi. pertama, lebih mementingkan pelayanan kemanusiaan yang ideal dibandingkan 
dengan kepentingan pribadi. kedua, seorang pekerja profesional, secara relatif memerlukan waktu yang panjang untuk mempelajari konsep-konsep serta prinsip-prinsip pengetahuan khusus yang mendukung keahliannya. ketiga, memiliki kualifikasi tertentu untuk memasuki profesi tersebut serta mampu mengikuti perkembangan dalam pertumbuhan jabatan. keempat, memiliki kode etik yang mengatur keanggotaan, tingkah laku, sikap dan cara kerja. kelima, membutuhkan suatu kegiatan intelektual yang tinggi. keenam, adanya organisasi yang dapat meningkatkan standar palayanan, disiplin diri dalam profesi, serta kesejahteraan anggotanya. ketujuh, memberikan kesempatan untuk kemajuan, spesialisasi dan kemandirian, dan kedelapan, memandang profesi sebagai suatu karier hidup (a live career) dan menjadi seorang anggota yang permanent

\section{B. PENGERTIAN PROFESI}

Kebanyakan kita mengatakan bahwa mengajar adalah suatu profesi. Lalu apakah yang dimaskud dengan profesi, dan syarat-syarat serta criteria yang harus dipenuhi agar suatu jabatan dapat disebut suatu profesi. Ornstain dan Levine menyatakan bahwa profesi adalah jabatan yang berfungsi untuk melayani masyarakat, yakni merupakan karir yang akan dilaksanakan sepanjang hayat (tidak berganti-ganti pekerjaan), merupakan bidang ilmu dan katrampilan tertentu diluar jangkauan halayak ramai (tidak setiap orang dapat melakukannya), terkendali berdasarkan lisensi baku dan atau mempunyai persyaratan masuk (untuk menduduki jabatan tersebut memerlukan izin tertentu atau ada persyaratan khusus yang ditentukan untuk dapat mendudukinya) serta menerima tanggungjawab terhadap keputusan yang diambil dan untuk kerja yang ditampilkan yang berhubungan dengan layanan yang diberikan. ${ }^{1}$

Dalam kehidupan sehari-hari "profesionalisme" dan "profesi" telah menjadi kosa kata umum. Seringkali terdengar orang mengatakan "cara orang itu melaksanakan usaha atau bisnis tidak profesional" dan kini sangat banyak orang menganggap bahwa setiap orang dapat mengerjakan suatu pekerjaan dengan baik, rapi dan dapat memuaskan orang lain. Cara kerja yang demikian itu disebut sebagai telah menyelesaikan pekarjaan secara profesioanal. Sehingga hampir kepada siapa saja dengan mudah mensyaratkan memberikan gelar professional.

${ }^{1}$ Soetjopto, Prof, Roflis kosasi, Drs, M.Sc, "Profesi Keguruan” (Yogyakarta:

Rineka Cipta, September 2009), hlm 16 
Setiap orang apapun jenis profesinaya memiliki hak selaigus kewajiban yang harus mereka tunaikan. Dalam hal ini Mahatma Ghandi berpesan bahwa "semua hak itu diperoleh dari kewajiban yang telah ditunaikan dengan baik". Kaidah umum ini berlaku secara universal untuk semua profesi termasuk guru sebagai profesi. ${ }^{2}$

\section{SYARAT-SYARAT PROFESI}

Konvensi Nasional Pendidikan Indonesia pada tahun 1988, menentukan syarat-syarat suatu pekerjaan profesional sebagai berikut : (1) atas dasar panggilan hidup yang dilakukan sepenuh waktu serta untuk jangka waktu yang lama, (2) telah memiliki pengetahuan dan keterampilan khusus, (3) dilakukan menurut teori, prinsip, prosedur, dan anggaananggapan dasar yang sudah baku sebagai pedoman dalam melayani klien, (4) sebagai pengabdian kepada masyarakat, bukan mencari keuntungan finansial, (5) memiliki kecakapan diagnostik dan kompetensi aplikatif dalam melayani klien, (6) dilakukan secara otonom yang bisa diuji oleh rekan-rekan seprofesi, (7) mempunyai kode etik yang dijunjung tinggi oleh masyarakat, dan (8) pekerjaan yang dilakukan untuk melayani mereka yang membutuhkan. ${ }^{3}$

Muchlas Samani dkk, mengemukakan syarat-syarat profesi meliputi: (1) memiliki fungsi yang signifikan dalam kehidupan masyarakat dimana profesi berada, (2) memerlukan keahlian dan keterampilan tertentu yang tidak dapat dijangkau oleh masyarakat awam pada umumnya, (3) keahlian yang diperlukan dikembangkan berdasarkan disiplin ilmu yang jelas dan sistematik, (4) memerlukan pendidikan atau pelatihan yang panjang, sebelum seseorang mampu memangku profesi tersebut, (5) memiliki otonomi dalam membuat keputusan yang terkait dengan ruang lingkup tugasnya, (6) memiliki kode etik jabatan yang menjelaskan bagaimana profesi itu harus dilaksanakan oleh orang-orang yang memegangnya, (7) memiliki organisasi profesi yang merupakan tempat pemegang profesi berasosiasi dan mengembangkan profesi tersebut. ${ }^{4}$

\footnotetext{
${ }^{2}$ Supolon, Dr, M.Eo, “Guru sebagai Profesi” (Yogyakarta: Hikayat), hlm. 58

${ }^{3}$ Made Pidarta, Landasan Kependidikan. (Jakarta : Renika Cipta, 2000), hlm. 266 hlm. 3-4

${ }^{4}$ Muchlas Samani, dkk, Pembinaan Profesi Guru. (Jakarta : Depdiknas, 2003),
} 
Bila kita bandingkan persyaratan yang dikemukakan oleh beberapa ahli tersebut, dapatlah disimpulkan pernyataannya hampir sama dan saling melengkapi. Dengan demikian bahwa persyaratan profesi yang dimaksud adalah sebagai berikut:

1. Memiliki spesialisasi ilmu dengan latar belakang yang baku

Yang dimaksud dengan spesialisasi ilmu adalah suatu keahlian khusus yang tidak dimiliki oleh pemegang profesi lain. Jadi keahlian khusus hanya ada pada profesi tersebut. Bila pekerjaannya adalah guru, maka keahlian mendidik harus ada dan melekat pada profesi guru tersebut. Spesialisasi tersebut juga harus didasarkan dengan teori yang sangat luas, artinya didasarkan pada teori yang baku dan universal menurut teori-teori pendidikan kalau misal profesinya itu adalah guru.

2. Memiliki kode etik dalam menjalankan profesi

Michael D Bayles, mengungkapkan sebuah kode etik profesi yang umum sebagai berikut: (1) kewajiban adalah norma-norma yang berisi apa yang benar dan apa yang salah untuk dilakukan, (2) Izin yaitu penolakan terhadap sesuatu yang bertentangan dengan kewajiban profesi, misalnya menolak pemberian kliennya yang mengusulkan perbuatan amoral atau apa saja yang bertentangan dengan norma-norma profesi. ${ }^{5}$

3. Memilki organisasi profesi

Tujuan dari organisasi profesi adalah untuk meningkatkan peran serta dirinya dalam hal-hal yang berhubungan dengan keprofesian. PGRI (Persatuan Guru Republik Indonesia) sebagai organisasi keguruan memiliki peran dan tangggung jawab untuk menjaga, memelihara, dan mengembangkan profesi keguruan. ${ }^{6}$ Menjaga antara lain berupaya agar layanan pendidikan mutunya dapat dipertanggungjawabkan secara profesional. Memelihara artinya mengupayakan profesi kependidikan dari pencemaran. Membangun berarti berupaya meningkatkan kualifikasi dan kualitas kemampuan profesional tenaga guru.

${ }^{5}$ Kadir Jaeani, Profesionalisme Pengawas Pendais (Jakarta: Dirjen Pembinaan Kelembagaan Agama Islam Depag RI 2000), hlm. 14 ${ }^{6}$ Soedijarto. Memantapkan Sistem Pendidikan Nasional, (Jakarta: PT Gramedia Widiya Sarana Indonesia, 1993), hlm.114 


\section{Diakui oleh masyarakat}

Diantara faktor penunjang keprofesionalan seorang profesi adalah adanya pengakuan dari orang lain (masyarakat). Begitu juga bagi orang yang berprofesi sebagai guru, selain eksistensinya sebagai social worker yang dibutuhkan oleh masyarakat bukan hanya sebagai agen of change, tetapi juga pengakuan terhadap profesinya yang layak dimata masyarakat.

\section{Sebagai panggilan hidup}

Profesi dipilih sebagai panggilan hidup. Maksudnya profesi itu dipilih karena yang dirasakan dan diyakininya itulah panggilan hidup. Suatu profesi bukan hanya dimaksudkan untuk mencari keuntungan bagi dirinya, baik dari sisi ekonomis maupun psikis, melainkan untuk pengabdian masyarakat. Ini berarti suatu profesi tidak boleh sampai merugikan, merusak, atau menimbulkan malapetaka bagi orang lain ataupun masyarakat. Sebaliknya suatu profesi harus memberikan kemanfaatan dan kesempurnaan bagi masyarakat. Profesi sebagai panggila hidup berarti harus lebih mengutamakan kepentingan orang lain daripada kepentingan dirinya. Misalnya profesi guru adalah untuk kepentingan kemajuan anak didiknya.

\section{Harus dilengkapi kecakapan diagnostik}

Kecakapan diagnostik adalah kecakapan dalam mengidentifikasi masalah yang bersangkutan dengan klien, atau masalah yang berkaitan dengan teori-teori dalam bidang profesinya. Kemampuan mendiagnosis sebenarnya merupakan kemampuan mengenali masalah, mencakup apa penyebabnya, dan bagaimana cara penyelesaiannya. Salah satu contoh misalnya, ketika ada salah satu siswa sering tidak masuk sekolah tanpa ada keterangan yang jelas, maka seorang guru yang bijak tidak kemudian menyebut bahwa anak didiknya itu malas dan lain sebagainya, akan tetapi alangkah bijaknya andaikata guru tersebut home visit dan bertemu dengan kedua orang tuanya seraya mencari tahu apa alasan yang sebenarnya sampai anak tersebut sering tidak masuk tanpa ada keterangan, sehingga dari sini guru mampu dan bisa tahu hakikat dari kondisi peserta didiknya.

7. Mempunyai klien yang jelas

Maksud dari klien disini adalah user atau pengguna jasa profesi seseorang, kalaulah profesinya itu sebagai dokter maka pasien adalah kliennya, kalau kemudian profesinya itu seorang guru, maka yang menjadi kliennya adala para siswa atau peserta didiknya masing-masing.

Ke tujuh kriteria profesi itu hanya ada pada profesi pada umumnya, sehingga jika sebuah profesi kurang memenuhi kriteria yang 
telah disebutkan maka tidak sempurna pula sebuah profesi yang dijalankannya.

\section{CIRI-CIRI PROFESIONAL}

Berdasarkan pengertian di atas, dapat dipahami bahwa seorang dikatakan profesional, karena ia mempunyai standar kualitas dan ciri-ciri tertentu. Menurut Anwar Jasin, ciri mendasar dari sebuah makna profesional tersebut antara lain: pertama, tingkat pendidikan spesialisasinya menuntut seseorang melaksanakan jabatan/pekerjaan dengan penuh kapabilitas, kemandirian dalam mengambil keputusan (independent judgement), mahir dan terampil dalam mengerjakan tugasnya.

Kedua, motif dan tujuan utama seseorang memilih jabatan/pekerjaan itu adalah pengabdian kepada kemanusiaan, bukan imbalan kebendaan (bayaran) yang menjadi tujuan utama. Ketiga, terdapat kode etik jabatan yang secara sukarela diterima mejadi pedoman perilaku dan tindakan kelompok profesional yang bersangkutan. Kode etik tersebut menjadi standar perilaku pekerjaannya. Keempat, terdapat kesetia-kawanan seprofesi, yang diwujudkan dengan saling menjalin kerja sama dan tolong menolong antar anggota dalam suatu komunitas tertentu.7

Masih mengenai ciri-ciri profesional, pandangan yang hampir senada dengan Jasin juga diungkapkan oleh Tilar, bahwa para profesional mempunyai ciri-ciri khusus. Mereka sesungguhnya bekerja untuk mengabdi pada suatu profesi. Adapun ciri-ciri dari suatu profesi itu adalah memiliki suatu keahlian, merupakan panggilan hidup, memiliki teori-teori yang baku secara universal, mengabdikan diri untuk masyarakat dan bukan untuk diri sendiri, dilengkapi dengan kecakapan diagnostik dan kompetensi yang aplikatif, memiliki otonomi dalam melaksanakan pekerjaannya, mempunyai kode etik, mempunyai klien yang jelas, mempunyai organisasi yang kuat, dan mempunyai hubungan dengan profesi pada bidang-bidang yang lain. 8

${ }^{7}$ Anwar Jasin, "Pengembangan Profesionalisme Guru dalam rangka Peningkatan Mutu Sumber Daya Manusia, dalam M. Dawam Raharjo, [ed.], Keluar dari Kemelut Pendidikan Nasional, Menjawab Tantangan Kualitas Sumber Daya Manusia Abad 2”1, (Jakarta: Intermasa, 1997), hlm. 35-34.

${ }^{8}$ H.A.R Tilaar, "Paradigma Baru Pendidikan Nasional", (Jakarta: Rineka Cipta, 2000), hlm. 137-138. 
Sementara menurut Roestiyah, seorang profesional paling tidak memiliki ciri atau kreteria sebagai berikut. Pertama, berpendidikan professional.. Kedua, mengakui sadar profesinya. Jadi memiliki sikap dan mampu mengembangkan profesinya, dan tidak bermaksud untuk menjadikannya sebagai batu loncatan untuk memasuki profesi lain. Ketiga, menjadi anggota profesionalnya, yang dapat pengakuan pemerintah maupun masyarakat. Keempat, mengakui dan melaksanakan kode etik profesional yang tanpak pada usaha untuk mengembangkan profesi serta ilmu, pengembangan diri, dan mengakui serta menghormati norma-norma masyarakat. Kelima, pengembangan diri dan profesi ini bukan karena tekanan dari luar maupun karena profesi itu, melainkan timbul dari dalam diri yang bersangkutan. Keenam, ikuti berpartisipasi dengan memanfaatkan alat komunikasi dengan antar anggotanya maupun dengan pihak lembaga lain di luar organisasi profesionalnya. Komunikasi itu antara lain dapat berbentuk publikasi ilmiah dan sebagainya, dan ketujuh, dapat bekerja sama dengan anggota maupun organisasi profesional lain, baik sebagai individu maupun di dalam rangka organisasi. ${ }^{9}$

Dengan kreteria tersebut, seorang profesional merupakan hasil dari suatu yang dipersiapkan dan dibina di pekerjaannya. Oleh sebab profesi tersebut terus berkembang sejalan dengan perkembangan ilmu pengetahuan dan teknologi, maka seorang profesional adalah seorang yang secara berkembang. Perkembangan dari seorang profesional tentunya akan lebih mudah apabila mereka mempunyai dasar-dasar ilmu pengetahuan yang kuat.

Menurut Tantri Abeng, Istilah profesional memiliki aspek-aspek tertentu. Aspek yang dimaksud adalah menyangkut masalah ilmu pengetahuan (knowledge), aspek ketrampilan (skill), serta sikap mental (attitude). Untuk yang terakhir ini menjadi catatan khusus, yang melekat dalam diri profesional. Artinya terbuka terhadap pandangan ataupun nilainilai baru yang lebih positif dan menerima perbedaan pendapat serta berlaku jujur. Lebih lanjut, Tantri Abeng mengemukakan bahwa aspek pengetahuan, ketrampilan dan sikap mental setara dan sama petingnya sebagai fondasi untuk membangun kualitas dan mutu profesional. ilmu pengetahuan diperoleh dari hasil pendidikan, oleh sementara ahli disyaratkan sampai pada advanced educational, sedang skill atau keahlian

${ }^{9}$ Roestiyah, “Masalah-Masalah Ilmu Keguruan”, (Jakarta: Bina Aksara, 1989), hlm. 175 . 
di dapat dari latihan, dan aktivitas melaksanakan pekerjaan atau learned on the job. Adapun attitude atau sikap mental merupakan kepribadian, tetapi bisa dididik lewat pendidikan agama dan pendidikan moral sejak dini, di samping tuntutan yang berasal dari lingkungannya. ${ }^{10}$

\section{E. TENAGA PENDIDIK SEBAGAI PROFESI}

Guru sebagai pendidik adalah tokoh yang paling banyak bergaul dan berinteraksi dengan para murid dibanding dengan personil lainya disekolah. Guru bertugas merencanakan dan melaksanakan proses pembelajaran, menilai hasil pembelajaran, melakukan bimbingan dan pelatihan, melakukan penelitian dan pengkajian dan membuka komunikasi dengan masyarakat. Guru kelas di SD dan guru bidang studi di SMP dan menengah mengemban kewajiban untuk turut aktif membantu melaksanakan berbagai program belajar. Terutama menyangkut mata pelajaran yang duiasuhnya. Menggerakkan dan mendorong peserta didik benar-benar dapat menguasai bidang ilmu yang dipelajari. Bukan saja sekedar turut mengikuti pelajaran, akan tetapi lebih dari pada itu. Guru mata pelajaran juga harus ikut membantu peserta didik untuk dapat memperoleh pembinaan yang sesuai dengan bakat, minat dan kemampuan yang dimiliki. Guru juga dapat dikategorikan sebagai ilmuan dan cendekiawan.

Blau, peter M (1973) menjelaskna ilmuan tidak mempunyai klien, oleh karena itu mereka tidak bisa disebut professional, karena para professional mempunyai klien berkenaan dengan keprofesian para para professional tersebut. Makanya para akademisi dalam peranannya sebagai ilmuan dan cendekiawan bukanlah termasuk professional. Jika dipandang dari titik pusat professional, yaitu adanya alur dasar yang tinggi, prestise, pengaruh, persyaratan tinggi, otonomi profersional, surat izin dan komitmen para anggota terhadap profesinya bahwa hal ini semua juga dimiliki oleh akademisi dan guru kecuali mungkin pendapatan yang tinggi

\section{F. SYARAT MENJADI GURU PROFESIONAL}

Profesi guru masih dihadapkan kepada banyak permasalahan, karena profesi guru merupakan suatu profesi yang sedang tumbuh, semua

${ }^{10}$ Tantri Abeng, “Dari Meja Tantri Abeng, Gagasan, Wawasan, Terapan dan Renungan”, (Jakarta: Pustaka Sinar Harapan, 1997) hlm. 3 
permasalahanya masih relevan dibicarakan, salah satu diantaranya profesi harus melalui pendidikan tinggi keguruan. Hal ini sejalan dengan UU No. 14 tahun 2005 Pasal 8 menyatakan guru wajib memiliki kualifikasi akademik, kompetensi, sertifikat pendidik, sehat jasmani dan rohani serta memiliki kemampuan untuk mewujudkan tujuan pendidikan nasional. Standar yang dipersyaratkan menjadi guru yang professional meliputi tugas dan tanggung jawab guru, peningkatkan kualitas, standar keprofesionalan, serta kode etik dan kepribadian guru. ${ }^{11}$

1. Tugas dan tanggung jawab guru

Guru sebagai profesi secara holistic adalah berada pada tingkatan tertinggi dalam system pendidikan nasional. Karena guru dalam melaksanakan tugas profesionalnya memiliki otonomi yang kuat. Adapun tugas guru sangat banyak baik yang terkait dengan kedinasan dan profesinya disekolah. Seperti mengajar dan membimbing para muridnya, memberikan penilaian hasil belajar peserta didiknya, mempersiapkan administrasi pembelajaran yang diperlukan dan kegiatan lain yang diperlukan dalam pembelajaran, disamping itu guru haruslah senantiasa berupaya meningkatkan dan mengembangkan ilmu yang menjadi bidang studinya agar tidak ketinggalan jaman, ataupun diluar kedinasan yang terkait dengan tugas kemanusiaan dan kemasyarakatan secara umum diluar sekolah.

Guru tidak boleh terisolasi dari perkembangan social masyarakatnya. Tugas guru sebagai pendidik merupakn tugas mewariskan ilmu pengetahuan dan teknologi kepada muridnya. Kemudian muridnya belajar memperoleh dan mengembangkan ketrampilan berlatih menerapkan demi kemanfatan yang lebih besar juga dari gurunya. Guru professional siap difungsikan sebagai orangtua kedua bagi para muridnya setelah orangtua kandung sebagai orangtua pertama, itulah sebabnya guru perlu menguasai ilmu jiwa dan watak manusi untuk dapat diterapi dan dilayani secara tepat oleh para guru. ${ }^{12}$

2. Kode etik guru sebagai profesi

Sebagai sorang yang professional guru harus memilki kode etik yang akan menjadi pedoman dalam melaksanakan profesinya. Kode etik

${ }^{11}$ Syaiful Sagal, Prof, H, "kemampuan Profesional Guru dan Tenaga Kepndidikan" (Bandung: AlfaBeta, Januari 2009), hlm. 2-26

${ }^{12}$ Syaiful Sagal, Prof, H, "kemampuan Profesional Guru dan Tenaga Kepndidikan" (Bandung: AlfaBeta, Januari 2009), hlm. 2-26 
tersebut disusun oleh organisasi profesi, di Indonesia disebut Persatuan Guru Republik Indonesia (PGRI), selain itu ada beberapa organisasi lain yang anggotanya juga guru misalnya Musyawaroh guru mata pelajaran (MGMP) untuk guru SMP, SMA dan SMK, Kelompok Kerja Guru (KKG) untuk guru SD, Ikatan sarjan pendidikan Indonesia (ISPI), dan sebagainya.

Keikut sertaan guru dalam berbagai macam organisasi profesi tersebut diharapkan dapat meningkatkan mutu profesionalisme guru. Berbagai jenis kegiatan organisasi tersebut, seperti seminar pendidikan, loka karya, dan sebagainya, secara langsung maupun tidak langsung akan memberikan wawasan tetang pelaksanaan tugas profesionalnya. Sebagai perbandingan, diamerika serikat terdapat organisasi yang diberi nama National Council for Social Studies (NCSS) atau Dewan Nasional untuk Guru IPS, yang setiap tahun menyelenggarakan konvensi secara nasional. Dalam kegiatan konvensi nasional ini, para Guru IPS dari berbagai Negara bagian di Amerika Serikat mengambil bagian dalam berbagai acara seminar yang membahas berbagai topic penting, seperti kurikulum, strategi dan metode mengajar, pameran media dan alat peraga, serta buku pelajaran yang dapat menjadi media bagi upaya peningkatan profesionalisme guru. Adapun kode etik guru antara lain:

a. Guru berbakti membimbing peserta didik untuk membentuk manusia Indonesia seutuhnya yang berjiwa pancasila.

b. Guru memiliki dan melaksanakan kejujuran professional.

c. Guru berusaha memperoleh informasi tentang peserta didik sebagai bahan melakukan bimbingan dan pembinaan.

d. Guru menciptakan suasana sekolah sebaik-baiknya yang menunjang berhasilnya proses belajar mengajar.

e. Guru memelihara hubungan baik dengan orang tua murid dan masyarakat sekitarnya untuk membina peran serta dan rasa tanggung jawab bersama terhadap pendidikan.

f. Guru secara pribadi dan bersama-sama mengembangkan dan meningkatkan mutu dan martabat profesinya.

g. Guru memelihara hubungan seprofesi, semangat kekeluargaan dan kesetiakawanan social.

h. Guru secara bersama-sama memelihara dan meningkatkan mutu organisasi PGRI, sebagai sarana perjuangan dan pengabdian. 
i. Guru melaksanakan segala kebijakan pemerintah dalam bidang pendidikan. ${ }^{13}$

3. Guru professional senantiasa meningkatkan kualitasnya

Tugas dan kewajiban guru baik yang terkait langsung dengan proses belajar maupun tidak terkait langsung, sangatlah banyak dan berpengaruh pada hasil belajar mengajar. Bila peserta didik mendapatkan nilai tinggi maka guru mendapat pujian. Pantas menjadi guru dan harus dipertahankan, walaupun tetap disebut sebagai pahlawan tanpa tanda jasa. Akan tetapi apabila yang terjadi sebaliknya, yakni para peserta didik mendapatkan nilai rendah, maka serta merta juga kesalahan ditumpahkan kepada sang guru. Predikat guru bodoh, tidak bisa mengajar, tidak memiliki kemampuan menjalankan tugasnya sebagai guru, lebih baik beralih fungsi menjadi karyawan atau tata usaha juga dialamatkan kepada guru. ${ }^{14}$

Oleh karena itu perlu diperhatikan secara sungguh-sungguh bagaimana memberikan prioritas yang tinggi kepada guru. Sehingga mereka dapat memeperoleh kesempatan untuk selalu meningkatkan kemampuan melaksanakan tugas sebagai guru. Guru harus diberikan kepercayaan, untuk melaksanakan tugasnya melakukan proses belajar mengajar dengan baik. Kepada guru perlu diberikan dorongan dan suasana yang kondusif untuk menemukan berbagai alternative metode dan cara mengembangkan proses pembelajaran sesuai dengan perkembangan zaman. Agar dapat meningkatkan keterlibatanya dalam melaksanakan tugas sebagai guru, dia harus memahami, menguasai dan terampil menggunakan sumber-sumber belajar baru didirinya. Sumber belajar bukan hanya guru, apabila guru tidak mampu menyesuaikan diri dengan perkembangan perubahan maka guru tersebut akan mudah ditinggalkan oleh muridnya. ${ }^{15}$

4. Kompetensi guru yang Profesional

Kompetensi merupakan peleburan dari pengetauan (daya pikir), sikap, ketrampilan yang diwujudkan dalam bentuk perbuatan. Dengan kata lain, kompetensi merupakan perpaduan dari penguasaan pengetahuan,

${ }^{13}$ Supolom, Dr, M.Eo, “Guru sebagai Profesi” (Ypyakarta: Hikayat), hlm. 61-

${ }^{14}$ Syaiful Sagal, Prof, H, “kemampuan Profesional Guru dan Tenaga

Kepndidikan" (Bandung: AlfaBeta, Januari 2009), hlm. 2-26

${ }^{15}$ Syaiful Sagal, Prof, H, "kemampuan Profesional Guru dan Tenaga Kepndidikan" (Bandung: AlfaBeta, Januari 2009), hlm. 2-26 
ketrampilan, nilai dan siklap yang direfleksikan dalam kebiasann berfikir dan bertindak dalam melaksanakan tugas atau pekerjaan guna mencapai standar kualitas dalam pekerjaan nyata. Jadi kompetensi adalah seperangkat pengetahuan, ketrampilan perilaku, yang harus dimiliki dihayati dan dikuasai oleh guru untuk dapat melaksanakan tugas-tugas profesionalnya.

Berangkat dari keyakinan adayanya perubahan peningkatan status guru menjadi tenaga professional, dan apresisai lingkungan yang tinggi. Tentunya kompetesni merupakan langkah penting yang perlu ditingkatkan kompetensi intelektual merupakan berbagai perangkat pengetahuan dalam diri individu, diperlukan untuk menunjang berbagai aspek untuk kerja sebagai guru professional. Hal ini dapat digali dengan program peningkatan kualitas diri dari pemerintah sedangkan kompetensi fisik dan individu, berkaitan erat dengan perangkat perilaku yang berhubungan dengan kemampuan individu dalam mewujudkan dirinya sebagai kompetensi guru terfokus dalam kemapuan mendidik. Sementara itu, kompetensi dosen mencakup kemampuan mendidik, meneliti, dan mengabdi pada masyarakat. ${ }^{16}$

\section{G. KESIMPULAN}

Profesi merupakan pekerjaan yang di dalamnya memerlukan sejumlah persyaratan yang mendukung pekerjaannya. karena itu, tidak semua pekerjaan menunjuk pada sesuatu profesi. Guru sebagai profesi secara holistic adalah berada pada tingkatan tertinggi dalam system pendidikan nasional. Karena guru dalam melaksanakan tugas profesionalnya memiliki otonomi yang kuat. Adapun tugas guru sangat banyak baik yang terkait dengan kedinasan dan profesinya disekolah. Seperti mengajar dan membimbing para muridnya, memberikan penilaian hasil belajar peserta didiknya, mempersiapkan administrasi pembelajaran yang diperlukan dan kegiatan lain yang diperlukan dalam pembelajaran, disamping itu guru haruslah senantiasa berupaya meningkatkan dan mengembangkan ilmu yang menjadi bidang studinya agar tidak ketinggalan jaman, ataupun diluar kedinasan yang terkait dengan tugas kemanusiaan dan kemasyarakatan secara umum diluar sekolah.

${ }^{16} \mathrm{Ibid}$, hlm. 3-26 
Guru sebagai pendidik adalah tokoh yang paling banyak bergaul dan berinteraksi dengan para murid disbanding dengan personil lainya disekolah. Guru bertugas merencanakan dan melaksanakan proses pembe;lajaran, meniilai hasil pembelajaran, melakukan bimbingan dan pelatihan, melakukan penelitian dan pengkajian dan membuka komunikasi dengan masyarakat. Guru kelas di SD dan guru bidang studi di SMP dan menengah mengemban kewajiban untuk turut aktif membantu melaksanakan berbagai program belajar. Terutama menyangkut mata pelajaran yang duiasuhnya. Menggerakkan dan mendorong peserta didik benar-benar dapat menguasai bidang ilmu yang dipelajari. Bukan sekedar bukan saja sekeddar turut mengikuti pelajaran, akan tetapi lebih dari pada itu. Guru mata pelajaran juga harus ikut membantupeserta didik untuk dapat memperoleh pembinaan yang sesuai dengan bakat, minat dan kemampuan yang dimiliki. Guru juga dapat dikategorikan sebagai ilmuan dan cendekiawan. 


\section{DAFTAR PUSTAKA}

Anwar Jasin, "Pengembangan Profesionalisme Guru dalam rangka Peningkatan Mutu Sumber Daya Manusia, dalam M. Dawam Raharjo, [ed.], Keluar dari Kemelut Pendidikan Nasional, Menjawab Tantangan Kualitas Sumber Daya Manusia Abad 2”1, (Jakarta: Intermasa, 1997)

H.A.R Tilaar, "Paradigma Baru Pendidikan Nasional”, (Jakarta: Rineka Cipta, 2000)

Kadir Jaeani, Profesionalisme Pengawas Pendais (Jakarta: Dirjen Pembinaan Kelembagaan Agama Islam Depag RI 2000)

Made Pidarta, Landasan Kependidikan. (Jakarta : Renika Cipta, 2000)

Muchlas Samani, dkk, Pembinaan Profesi Guru. (Jakarta : Depdiknas, 2003)

Prof, Roflis kosasi Soetjopto, M.Sc, "Profesi Keguruan" (Yogyakarta: Rineka Cipta, September 2009)

Roestiyah, "Masalab-Masalab Ilmu Keguruan", (Jakarta: Bina Aksara, 1989)

Soedijarto. Memantapkan Sistem Pendidikan Nasional, (Jakarta: PT Gramedia Widiya Sarana Indonesia, 1993)

Supolom, Dr, M.Eo, "Guru sebagai Profesi” (Ypyakarta: Hikayat)

Syaiful Sagal, Prof, H, “kemampuan Profesional Guru dan Tenaga Kepndidikan" (Bandung: AlfaBeta, Januari 2009)

Tantri Abeng, "Dari Meja Tantri Abeng, Gagasan, Wawasan, Terapan dan Renungan", (Jakarta: Pustaka Sinar Harapan, 1997) 